\title{
POCZĄTKI KARIERY NAUCZYCIELSKIEJ KS. J. SCHINDLERA NA UNIWERSYTECIE JAGIELLOŃSKIM W LATACH 1832-1836
}

Ksiądz Jan Schindler (1802-1890) już za życia był uznawany za postać kontrowersyjną. Także i w obecnych czasach, zwłaszcza w środowisku krakowskim, uważany jest za postać dyskusyjną. W okresie Rzeczypospolitej Krakowskiej (1815-1846) udało mu się zrobić szybką i zawrotną karierę, często w oparciu o kontakty z rządem austriackim.

Za przełomowy dla kariery Schindlera możemy uznać rok 1832. Albowiem w tymże roku dzięki protekcji abp. Ankwicza otrzymał on pozwolenie przesiedlenia się do Wolnego Miasta Krakowa ${ }^{1}$. Głównym celem przyjazdu Schindlera była nominacja na stanowisko profesora Pisma Świętego i języków wschodnich na Uniwersytecie Jagiellońskim².

Wydział Teologiczny Uniwersytetu Jagiellońskiego w latach 1804-1805, podobnie jak na innych uniwersytetach austriackich, posiadał nowy plan studiów. Wśród wykładanych dotąd przedmiotów pojawiły się nowe, takie jak: język hebrajski, wstęp do Pisma Świętego czy hermeneutyka biblijna. Podjęto uchwałę, że obok innych katedr na Wydziałach Teologicznych, powinny się też znaleźć katedry języków wschodnich oraz egzegezy Starego Testamentu ${ }^{3}$. Po śmierci profesora teologii dogmatycznej ks. Mikołaja Gillesa ${ }^{4}$ zawakowała katedra, którą on

' Por. J. B i en i arzówn a, A. S te lmach, PSB 35, 1994, s. 498; K. Hoszowski, Obraz życia i zasług opatów mogilskich, Kraków1867, s. 158.

2 Por. L. Z a r e w i c z, Dom kapitulny zwany dawniej św. Stanistawa biskupa, przy ulicy Kanonicznej w Krakowie, Kraków 1887, s. 86; por. K. M i c h a le w s k a, $Z$ dziejów nauczania orientalistyki na Uniwersytecie Jagiellońskim w latach 1818-1836, [w:] Szkice z dziejów polskiej orientalistyki, Wroclaw 1966, s. 116; por. K. T. S o c z y ń s k i, Uniwersytet Jagielloniski zreorganizowany w roku 1833, Solura 1834, s. 6-7.

${ }^{3}$ W. Z a j ą c z k ow ski, Z dziejów orientalistyki na UJ, [w:] Wydziat Filozoficzny UJhistoria katedr, Kraków 1964, s. 371.

${ }^{4}$ Gilles Mikołaj ks. (1745-1820) profesor teologii dogmatycznej Wydziału Teologicznego UJ. Urodził się we Francji. W 1793 roku już po święceniach kapłańskich przybył do Polski. Otrzymał doktorat na Wydziale Teologicznym Szkoły Głównej Koronnej dnia 19 I 1810 r. Natomiast 14 II 1815 objąl stanowisko profesora teologii dogmatycznej. Był kanonikiem akademickim, w 1818 roku otrzymał kanonię katedrę karniowska. W latach 1809-1820 był proboszczem w Przemykowie. Autor referatu O piękności Pisma św. Mianowicie pod względem bohaterskiey, dramatyczney i liryczney poezji. T. G 1 e m m a, Gilles Mikolaj, PSB 7, 1949, s. 470. 
obejmowal $^{5}$. Rada Wydziału Teologicznego w 1820 roku przewidziała tymczasowo na to stanowisko dziekana ks. F. Kudrewicza (w latach 1815/16-1830/31 wykładał on archeologię biblijną i hermeneutykę ST) ${ }^{6}$.

Od roku akademickiego 1827/28 na Wydziale Teologicznym ks. Piotr Pękalski wykładal języki wschodnie (mianowany w tym samym roku profesorem nadzwyczajnym nie otrzymywał jednak $\mathrm{z}$ tego tytułu wynagrodzenia) ${ }^{7}$. Program ks. Pękalskiego zakładał wprowadzenie gramatyki i słownictwa języków: hebrajskiego, syryjskiego, chaldejskiego. Dalej w toku ćwiczeń przechodził do zapoznawania studentów z budową stylistyczną owych języków. Trzeba tu dodać, że te wykłady nie były obowiązkowe na Wydziale Teologicznym Uniwersytetu Jagiellońskiego ${ }^{8}$.

Po przejściu przez ks. Kudrewicza na emeryturę w 1831 roku, powołano na tymczasowe zastępstwo na stanowisko profesora hermeneutyki ST ks. J. S. Przybylskiego (profesor teologii dogmatycznej) ${ }^{9}$. Z tego powodu, kolejny już raz, Rada Uniwersytetu ogłosiła konkurs $^{10}$ na katedrę Pisma św. Starego Testamentu i Języków Wschodnich (24 XI 1831) ${ }^{11}$. W owym ogłoszeniu przewidziano liczbę 4 godzin wykładów tygodniowo, a także określono zasady, na jakich mieli być przyjęci kandydaci: ,(...) ubiegający się o tę posadę obowiązani są złożyć w kancellaryi Uniwersytetu opis swego życia udowadniając zaświadczeniami swoje nauki - dobre obyczaje i otrzymany stopień Doktora Teologii... oraz program według którego każdy z nich życzy sobie dawać lekcyi publiczne Pisma św., które w języku łacińskim ma bydź wykładane..."12. Termin egzaminu ustalono na dzień 31 III 1832 roku, podano także wysokość pensji dla tej katedry, która wynosiła $4000 \mathrm{złp}^{13}$.

Ksiądz Jan Schindler w marcu 1832 roku zgłosił oficjalnie swoją kandydaturę rektorowi A. Estreicherowi ${ }^{14}$. W przesłanym liście do tegoż rektora $\mathrm{Z}$ dnia 25 III 1832 roku Schindler przedłożył manuskrypt i listy korespondencyjne (20 sztuk) ${ }^{15}$.

${ }^{5}$ M. K a n i o r, Wydziat Teologiczny w dziejach Uniwersytetu Krakowskiego (1780-1880), Kraków 1998, s. 217; por. R. W. S z w e d, Dzialalność spoleczna i polityczna biskupa krakowskiego K. Skórkowskiego, Częstochowa 2003, s. 164.

${ }^{6} \mathrm{~W} . \mathrm{Z}$ a j a c z k ow sk i, tamże, s. 371.

${ }^{7}$ M. K a n i o r, tamze, s. 221.

${ }^{8} \mathrm{~W} . \mathrm{Z}$ a jąc zk ow sk i, tamże, s. 371

${ }^{9}$ M. Ka n i or, tamże, s. 222.

${ }^{10}$ Archiwum Uniwersytetu Jagiellońskiego (dalej: AUJ), S I 309: Katedra Pisma św. i wykłady nadzwyczajne języków orientalnych z lat 1801-1849; por. M. K a n i o r, tamże, s. 222 (wcześniejsze konkursy nie mogły dojść do skutku ze względu na zaostrzone przepisy lub na nie wystarczający poziom edukacyjny kandydatów).

1 AUJ, S I 309, por. K. M i ch a lews ka, tamże, s. 116 (Autorka podaje inna, wcześniejszą datę ogłoszenia konkurau miañowicic 25 X 1831 ).

${ }_{12}^{12}$ AUJ, S I 309.

13 Tamże, S I 309.

${ }^{14}$ Estreicher Alojzy (1786-1852), botanik, rektor UJ. Urodzony w Krakowie, w 1802 roku rozpoczał studia na Wydziale Medycyny. W 1807 otrzymał stopień doktora medycyny (1811 - doktor filozofii). Mianowany w r. 1808 profesorem historii naturalnej i botaniki, a w latach 1831-1833 był rektorem UJ. Przeciwstawiał się polityce Wiednia, za co był usunięty ze stanowiska rektora, a później przez władze szykanowany. Miał ogromny wkład w kierowanie ogrodem botanicznym w Krakowie (1809-1843), który należał pod względem zasobności do największych w Europie. W. S z a f e r, Estreicher Alojzy, PSB 6,1948, s. 306-307.

${ }^{15}$ AUJ, WT I 10: Katedra Pisma św. i wykłady nadzwyczajne języków wschodnich $z$ lat 1800-1842. (Wśród spisu dolączonych allegatów wymienia m.in. 10 sztuk listownych kore- 
Oprócz tego dołączył dodatkowo komentarz do proroka Malachiasza (Malachias poliglotus) - był to tekst hebrajski z komentarzem w języku arabskim, łacińskim, niemieckim i polskim ${ }^{16}$. Zobowiazzał się też do nadesłania Gramatyki łacińskiej i Alkoranu w wypadku przyjęcia jego kandydatury ${ }^{17}$. Rektor Estreicher dnia 11 kwietnia 1832 roku przedstawił oficjalnie Wielkiej Radzie Uniwersytetu Senatu Akademickiego jedyną kandydaturę na obsadę katedry Pisma św., mianowicie ks. J. Schindlera. Zaskakującym jest fakt, iż rektor zgłaszając osobę Schindlera zaproponował, w myśl art. 85 Statutu Kuratorskiego, uwolnienie go od tego konkursu. Przy takim wyborze decyzji kierowano się tym, iż był on „mężem znanym i znakomitych talentów"18.

Niewatpliwie szczególna przychylność rektora ułatwiła Schindlerowi objęcie katedry, gdyż już w dniu zgłoszenia kandydatury przez Estreichera rozpatrzono ją pozytywnie przez Wydział Teologiczny ${ }^{19}$. Wydana uchwała tegoż Wydziału Teologicznego, potwierdzona dodatkowo przez bp. Karola Skórkowskiego (wielki kanclerz) upoważnia Senat Akademicki do przyjęcia kandydatury Schindlera i dnia 24 IV mianuje go profesorem Pisma Świętego i języków wschodnich ${ }^{20}$. Na podstawie tej uchwały, kilka dni później (27 IV), Senat Rządzący zamianował Jana Schindlera profesorem zwyczajnym, argumentując przy tym, że „,...) obok wysokiej umiejętności dowiódł gorliwości w zawodzie nauczycielskim....21.

Tego samego dnia rektor otrzymał patent dla Schindlera i 30 IV 1832 roku dziekan A. Krzyżanowski (w zastępstwie rektora) przesłał Schindlerowi zawiadomienie, o nadaniu mu nominacji na profesora Pisma Świętego na Wydziale Teologicznym Uniwersytetu Jagiellońskiego ${ }^{22}$. Został on także poproszony o jak najszybsze przybycie do Krakowa ,(...) w celu zainstalowania go na urząd profesora aktualnego w Kollegium Jurydynnem w Sali Zwyczajnej w obecności WJX. Dziekana Wydziału Teologicznego...,23.

Program jego wykładów został oceniony bardzo wysoko i uznany za niezwykle interesujący. Nie trudno się z tym zgodzić, gdyż obok innych przedmiotów wprowadził różne innowacje w zakresie omówienia zasad islamu czy interpretacji

spondencji literackiej z osobami uczonymi i bibliotekarzami oraz 10 statutów modlitwy Pańskiej w językach wschodnich: arabskim, marokańskim, perskim, szyickim, chaldejskim, hebrajskim, nowo- i starogreckim - zebrane w manuskrypt pt: Professio orthodoxa fideis ...).

${ }^{16}$ Biblioteka Jagiellońska (dalej: BJ), rkp. 4980; por. J. B i e n i a r zów n a, A. S te lm a c h, tamże, s. 498.

${ }_{17}$ AUJ, WT I, 10. (Drugim powodem, dla jakiego nie przesłał tych dzieł, było to, że były one bardzo pokaźne $i$ kosztowne. Opisał także swoje dokonania na polu naukowym $m$. in. thumaczenie i opisanie monet starożytnych - perskich, arabskich znajdujących się w klasztorach wiedeńskich).

${ }^{18}$ AUJ, S I 309; S I 78 (363): Protokół obrad Wielkiej Rady Uniwersytetu Jagiellońskiego $\mathrm{z}$ lat 1832-1845, s. 8; por. K. T. S o c z y ń s k i, Uniwersytet Jagielloński zreorganizowany..., s. 7 (,Za pośrednictwem p. Estreichera byłego rektora Uniwersytetu. Bez konkursu, z mniemanych tylko zalet, głębokiej uczoności w filologii i językach wschodnich, na katedrę profesora wykładów Pisma św. W tutejszym Uniwersytecie wakującą powołany...". Autor uważa, że instalacja Schindlera nie obyła się bez znajomości i odpowiednich układów).

\footnotetext{
${ }^{19}$ AUJ, S I 309.

${ }^{20} \mathrm{~J}$. B i e n i arzów na, A. Stel ma ch, tamże, s. 498.

${ }^{21}$ AUJ, S I 78 (363), s. 8.

${ }^{22}$ AUJ, S I 309; WT I 10; AP, IT 518.

${ }^{23}$ AUJ, WT I 10.
} 
Koranu (do wykładów przygotowywał różne rękopisy, sprowadził w tym celu egzemplarz Koranu). Jako pierwszy z profesorów zaczął kłaść nacisk na zapoznanie studentów $z$ religią muzułmańską ${ }^{24}$.

Plan wykładów składał się zasadniczo z trzech części. Część pierwsza dotyczyła wykładów Pisma św. Starego Testamentu oraz archeologii orientalnej. Materiały do tej części przygotowywał Schindler w oparciu o publikację Fundgruben des Orients wydawanej przez J. Hammera i W. Rzewuskiego w Wiedniu ${ }^{25}$. W części drugiej skupił się na przedstawieniu metod nauczania języków wschodnich biblijnych. Przy tej części korzystał z podręczników A. Oberleitnera Elementa armaicae seu chaldaeo-syriacae linguae z 1824 roku, a także J. Jahna Grammatica linguae hebraica $(1800)^{26}$. W ostatniej, trzeciej części zamieścił plan nauki filologii orientalnej, na którą składał się wykład języka arabskiego na podstawie wydania L. Marracciego (m.in. lektura Koranu), oprócz tego oparł się także na gramatyce A. Oberleitnera Fundamenta linguae arabicae $(1826)^{27}$.

Wykłady z języków wschodnich prowadzil dla studentów pierwszego roku w wymiarze trzech godzin tygodniowo, natomiast wykłady z języka arabskiego dla studentów drugiego roku (jedna godzina w tygodniu $)^{28}$. Zarówno poziom jak i zainteresowanie jego wykładami musiało być duże, skoro oprócz studentów Wydziału Teologicznego uczęszczali na nie takźe studenci $z$ innych wydziałów ${ }^{29}$.

W 1832 roku na 97 posiedzeniu zwyczajnym w dniu 12 listopada został przyjęty na czcigodnego członka Towarzystwa Naukowego Krakowskiego ${ }^{30}$. O jego zainteresowaniach może świadczyć odczyt jego pracy na posiedzeniu TNK pt: Główne zasady islamizmu (23 VI 1834) ${ }^{31}$. W czasie swoich późniejszych, zagranicznych podróży przywiózł dla Towarzystwa Naukowego wiele zbiorów. W 1840 roku podczas pobytu w uzdrowisku w Franzensbaudzie odkrył minerały i skamieniałości, które po powrocie ofiarowal Gabinetowi Mineralogicznemu ${ }^{32}$. Interesował się także filologią perską i turecką oraz numizmatyką muzułmańską.

Niespełna rok później (24 VIII 1833) Senat Rządzący, z woli Komisji Nadzwyczajnej do Reorganizacji władz Krakowa, powołał Schindlera na urząd dziekana Wydziału Teologicznego od dnia 1 IX 1833 roku $^{33}$. Ponieważ był to czas pracy nad nowym Statutem Organicznym, postanowiono, że okres jego kadencji jako dziekana zostanie skonkretyzowany dopiero po uchwaleniu wspomnianego

\footnotetext{
${ }^{24} \mathrm{~K} . \mathrm{Mich}$ a lew sk a, tamże, s. 118.

${ }^{25}$ W. Z a jąc zk ow ski, tamże, s. 372 ; por. K. M i cha lew sk a, tamże, s. 118.

${ }^{26}$ Zob. W. Z aj ąc zk ow s k i, tamże, s. 372.

${ }^{27}$ Zob. K. M i ch a l ew s ka, tamże, s. 118.

28 K Micha! e wak tamżc, s. 118.

29 J. B i en iarzówn a, A. Stel mach, tamże, s. 498; por. W. Z a jąc zkowski,
} tamże, s. 372 .

${ }^{30}$ Archiwum Polskiej Akademii Naukowej (dalej: A PAN), TNK 2: Protokoły posiedzeń z lat 1816-1834 (wraz z nim przyjęto też Jana Kantego Rzesińskiego b. Prezesa doktora oraz adwokata przy trybunałach WMK).

${ }^{31}$ A PAN, TNK 3: Protokoly posiedzeń z lat 1834-1856.

${ }^{32}$ A PAN, TNK 14: Korespondencja z lat 1840-1844; TNK 44: Dziennik podawczy z lat 1840-1860 (Wymienia tam minerały np.: „skamieniałe drzewo palmowe, nasiona owocowe w węgiel obrócone w głębokości 16-18 stóp leżące”).

${ }^{33}$ Archiwum Państwowe w Krakowie (dalej: AP), IT 518, Kopjarz dokumentów i aktów do zycia Jana Schindlera-Prezesa Senatu WMK (1802-1879). 
statutu $^{34}$. Oprócz dotychczasowej pensji za wykłady z archeologii i hermeneutyki oraz języków wschodnich (4000 złp) miał otrzymywać za sprawowany urząd dziekana pensję w wysokości $1000 \mathrm{zlp}^{35}$.

Przychylność dworów opiekuńczych przejawiała się m.in. w stosunkach Schindlera z ówczesnym przedstawicielem Austrii (rezydującym w Wolnym Mieście Krakowie) baronem Wilhelmem von Pflüglem, który to otrzymał od Schindlera w dowód ,przyjaźni" rękopis Próby pisma marokańskiego ${ }^{36}$.

Powstanie Listopadowe spowodowało zaostrzenie polityki mocarstw opiekuńczych w stosunku do Rzeczypospolitej Krakowskiej. W marcu 1833 roku przyjechali do Krakowa komisarze dworów opiekuńczych: W. von Pflügl (Austria), A. Forckenbeck (Prusy) oraz L. Tęgoborski (Rosja) ${ }^{37}$.

$\mathrm{Z}$ polecenia opiekuńczych rządów utworzone zostały komitety, które miały się zając zmianą konstytucji i obowiązujących statutów poszczególnych organów administracji, a także sprawami Uniwersytetu Jagiellońskiego i Instytutów Naukowych $^{38}$. Z profesorów uniwersyteckich do komitetów został powołany Schindler, a wraz z nim A. Krzyżanowski, J. Brodowicz ${ }^{39}$ i M. Weisse. Głównym ich zadaniem było przeprowadzenie reformy Uniwersytetu w myśl dyrektyw państw zaborczych i pełne uzależnienie go od władz. Na sekretarza Komisji wybrano Schindlera ${ }^{40}$.

Według Karola Soczyńskiego samo powolanie tej komisji bylo niezgodne z prawem nadanym Uniwersytetowi gdyż ,(..) jakkolwiek powyższy skład osób był zupełnie przeciwny prawom i przywilejom UJ zapewnionym, według których, tenże Uniwersytet przez żadną inną władzę, bądź świecką bądź duchowną, wizytowanym ani reformowanym być nie powinien, tylko przez Rząd, lub mocowaną

34 Tamze, IT 518.

35 AUJ, S I 136: Sklad osobowy Uniwersytetu, liceów i szkól podległych Uniwersytetowi $z$ lat 1796/97-1848/49 (W latach 1833-1835 przykładowo - komisarz rządowy K. Hübner jako urzędnik uniwersytecki zarabiał $-8000 \mathrm{ztp}$, rektor K. Hube -2000 , a profesor Brodowicz $6000 \mathrm{ztp})$

${ }^{36} \mathrm{~J}$. B i en i arzówn a, A. Stel mach, tamże, s. 498.

${ }^{37}$ M. K a n i or, tamże, s. 202

38 Tamże, s. 202. (Autor wymienia, że do komisji dla spraw Uniwersytetu zostali wybrani: F. Grodzicki [senator], ks. J. W. Łańcucki [archiprezbiter mariacki] oraz J. Mierosławski [szambelan dworu rosyjskiego]).

${ }^{39}$ Brodowicz Maciej Józef (1790-1885), profesor Uniwersytetu Krakowskiego. Urodził się w Grzymałowie. W 1810 roku rozpoczął studia lekarskie w Wiedniu. W 1817 r. uzyskał stopień doktora i pracował jako asystent kliniki profesora Raimanna w Wiedniu. Przez jakiś czas był także lekarzem przybocznym biskupa tarnowskiego ks. Zieglera. A dnia 15 II 1823 roku Rada Uniwersytetu Krakowskiego mianowała go profesorem kliniki lekarskiej. To z jego inicjatywy klinikę akademicką przeniesiono do nowego budynku (22 XI 1827 - budynek ten należał do Krakowskiego Towarzystwa Wolnomularzy). Klinikę położniczą umieszczono w szpitalu św. Łazarza, gdzie usytuowano ją w 1869 w dworku podarowanym przez Brodowicza. Byl trzykrotnym rektorem, mianowano go także Komisarzem Zakładów Naukowych WMK. Z ówczesnym prezesem ks. Schindlerem oprócz wspólnych interesów łączyła go wieloletnia przyjaźń. W 1849 roku zrezygnował z nauczania na Uniwersytecie i przeszedł w stan spoczynku. W tym też czasie wydał swoje wspomnienia Kwiatki polne. Zmarł 22 I 1885 roku. L. W a c h o l z, Brodowicz Maciej Józef, PSB 2, Kraków 1936, s. 443-444.

${ }^{40}$ M. K a n i o r, tamże, s. 202. (Rektor został pominięty przy wyborze do komisji). 
przez niego osobę, wspólnie $\mathrm{z}$ rektorem i wybranymi między siebie na ten koniec profesorami..." 41 .

Prace nad tekstem Statutu komitet skończył w sierpniu 1833, po czym przedłożył go Komisji Reorganizacyjnej, która dnia 24 VIII 1833 r. wydała Statut Urzadzajacy Uniwersytet Jagiellonski ${ }^{42}$. Zaczął on obowiązywać od roku akademickiego $1833 / 34^{43}$.

Dalej według K. Soczyńskiego, pomiędzy Weisse, Schindlerem a Brodowiczem został zawiązany „ohydny triumwirat”, który współpracował ściśle z Konferencją Rezydentów, by wydać „(...) ustawę przechodnia, drukiem nie ogłoszona, w języku niemieckim świętokradczą ręką x. Schindlera pisanej..."44.

Postanowienia komitetu wywołały oburzenie i sprzeciw wśród profesorów Uniwersytetu Jagiellońskiego, wtedy zaczęto obwiniać Schindlera i Brodowicza za treść kontrowersyjnych artykułów Statutu ${ }^{45}$. Przykładowo, artykuł 47 przewidywał ,(...) iż tak piśmienne prace, jako też zdania profesorów o każdym kandydacie mają być przesyłane do zagranicznych uniwersytetów w celu wydania decyzji o usposobieniu kandydata na wakować mające katedry ubiegającego się..."46. Ten zapis w dużej mierze uzależniał Uniwersytet od zagranicznych uczelni, gdyż jedyna droga powołania profesorów był konkurs, który musiał być dodatkowo opiniowany przez uniwersytety państw opiekuńczych ${ }^{47}$.

Według M. Kaniora, Statut Organiczny „(...) ograniczył na Uniwersytecie swobodę wykładów, pozbawił rektora resztek władzy, oddał obsadzanie katedr dworom i zaprowadził ostre przepisy dyscyplinarne dla studentów...". Wybór rektora i dziekanów poszczególnych wydziałów odbywał się co dwa lata. Dodatkowo wybór rektora musiał być zatwierdzony przez Senat Rządzący ${ }^{48}$.

Zawarte nieformalne porozumienie pomiędzy wyżej wspomnianymi (Schindler, Brodowicz, Weisse) ułatwiało im kontrolę nad kadra profesorską i obsadzanie stanowisk „swoimi zwolennikami" ${ }^{49}$. Fryderyk Hechel uważał, że „(...) profesorowi nie wolno śmiało i otwarcie myśli swoje wykładać, gdyż łatwo słowa jego mogą być przekręcone i rezydentom doniesione, Ci jako wszechmocni, moga zburzyciela spokojności takiego profesora z kraju wydalić i na zawsze zgubić..."

Wydział Teologiczny w roku akademickim 1833/1834 miał czterech profesorów, z których tylko dwaj prowadzili wykłady: ks. Schindler, dziekan i profesor

${ }^{41} \mathrm{~K}$. S o c z yński, Uniwersytet Jagielloński zreorganizowany w roku 1833, Solura 1834, s. 5 .

${ }^{42}$ K. S o c z y ń s k i, Uniwersytet Jagielloński zreorganizowany.., s. 5; por. M. K a n i o r,

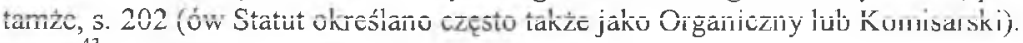

${ }^{43}$ M. Kanior, tamże, s. 203. drukiem).

${ }^{44}$ K. S o c z y ń s k i, tamże, s. 8 (tym samym potwierdza, że Statut nie został ogłoszony

${ }^{45}$ J. B i e ni arzów n a, A. S te $1 \mathrm{~m}$ a c h, tamże, s. 499.

${ }^{46} \mathrm{~K}$. S oczyń ski, tamże, s. 9.

${ }^{47}$ M. K a n i or, tamże, s. 203 (Konkursy z teologii opiniowala Akademia Duchowna Rzymsko-katolicka w Wilnie).

${ }^{48}$ Tamże, s. 203-204.

${ }^{49}$ K. S o c z y ń s k i, tamże, s. 9.

${ }^{50} \mathrm{~F}$. H e c h e l, Czlowiek nauki taki jakim byt, Kraków 1939, s. 57-58; por. M. K a n i o r, tamże, s. 204. 
Pisma św. i języków wschodnich, oraz ks. J. M. Janowski, profesor teologii pastoralnej i moralnej, wykładający zastępczo historię kościoła i patrystykę ${ }^{51}$.

Problemem, z jakim musiały się zmierzyć władze Uniwersytetu Jagiellońskiego w latach $1830-1840$, był stan liczbowy studentów na wydziałach, a zasadniczo ich brak. Najgorzej, wręcz katastrofalnie, sytuacja prezentowała się na Wydziale Teologicznym. Przyczynami takiego stanu było Powstanie Listopadowe a także polityka dworów opiekuńczych w stosunku do Uniwersytetu ${ }^{52}$. Dodatkowo, po klęsce Powstania wprowadzono zakaz studiowania w Krakowie dla wszystkich tych, którzy nie mają dodatkowego pozwolenia od rządu swojego kraju. Stąd władze austriackie utrudniały jeszcze bardziej młodzieży podejmowanie nauki na Uniwersytecie Jagiellońskim ${ }^{53}$.

Schindler, jako dziekan Wydziału Teologicznego, według poleceń Senatu Rządzącego wydał nakaz, by „(...) byli woyskowi polscy i osoby cywilne zagraniczne, które miały udział w rewolucyi Królestwa Polskiego w roku $1830 / 31 \ldots$ opuścity kraj tuteyszy..."54.

W roku 1832/33 na wykłady Schindlera z Pisma Świętego uczęszczało ośmiu słuchaczy z których pięciu w ciagu roku zrezygnowało ${ }^{55}$. Na rok akademicki 1835/36 zapisało się już tylko sześciu studentów. A w roku 1836/37 wyłącznie jeden student, który jeszcze $\mathrm{w}$ tym samym roku został skreślony $\mathrm{z}$ listy ${ }^{56}$. W końcu roku 1836/37 doszło do patowej sytuacji, gdyż Wydział Teologiczny nie posiadał już żadnych słuchaczy ${ }^{57}$. Braki uzupełniono wkrótce, poprzez przyjmowanie studentów pierwszego i drugiego roku filozofii, którzy ,,(..) uzupełniali braki w obowiązkowych przedmiotach na Wydziale Filozoficznym i starali się o potrzebne dokumenty..." 58 .

W czasie sprawowania przez Schindlera urzędu dziekana zainteresował się on ,sztuką kształcenia głuchoniemych”. Wraz z Brodowiczem i ks. Laurysiewiczem chcieli „(...) rozszerzyć w przyszłości sferę zbawiennego wpływu pasterzy duchownych na powierzone ich pieczy owieczki..." ${ }^{\circ 9}$. Na prośbę Schindlera Senat Akademicki wydał uchwałę, by ten przedmiot włączyć do programu nauczania (od 1840 r. na Wydziale Teologicznym stanowił on część katechetyki) ${ }^{60}$. Oprócz tego w roku 1837 Senat Akademicki przyznał doktorat honorowy teologii dla jednego z przedstawicieli tej dziedziny nauki w Wiedniu, ks. Franciszka Hermana Czecha ${ }^{61}$.

${ }^{51}$ M. K a n i o r, tamże, s. 223-225 (oprócz nich wymienia także ks. J. S. Przybylskiego, profesora zwyczajnego teologii dogmatycznej i moralnej i o. J. P. Kozłowskiego wykładającego teologię pastoralną i wymowę kaznodziejska).

${ }_{52}$ T. G 1 e m m a, Wydziat Teologiczny UJ w latach 1795-1847, Kraków 1949, s. 138; por. M. K a n i or, tamże, s. 256 .

${ }_{53}$ M. K a n i o r, tamże, s. 257.

${ }^{54} \mathrm{~T}$. G l e m m a, Wydzial Teologiczny..., s. 140

55 Tamże, s. 138.

${ }^{56}$ Tamże, s. 139; por. M. K a n i o r, tamże, s. 256-257 (tym studentem był ks. Antoni Jałoszyński, wikariusz przy kościele św. Floriana; powodem jego skreślenia było nieposiadanie przezeń "wyojczyźnienia" rządu austriackiego).

${ }^{57}$ T. Glemma, Wydziat Teologiczny.., s. 139; M. K a n i or, tamże, s. 256-257.

${ }^{58} \mathrm{~T}$. G l e m ma, tamże, s. 138.

${ }^{59}$ K. S o c z y ń s k i, tamże, s. 130.

${ }^{60}$ Tamże, s. 130; por. J. B i e n i a r zó w n a, A. S t e $1 \mathrm{~m}$ a c h, tamże, s. 498.

${ }^{61}$ K. S o c z y ń s k i, tamże, s. 130. 
Uniwersytet Jagielloński, wprowadzając tradycję nadawania tytułu doktora honorowego w XIX wieku, obdarzył także Schindlera tym zaszczytnym tytułem. W 1834 otrzymał stopień doktora obojga praw (4 VII 1834), natomiast (4 II 1840) doktorat honoris causa na Wydziale Filozoficznym ${ }^{62}$.

Schindler wykazywał się dużą skutecznością, przez co zyskał jeszcze większą przychylność dworów opiekuńczych ${ }^{63}$. Jego zaradność okazała się pożądaną cechą w roku akademickim 1833/34, kiedy to na Wydziale Teologicznym zawakowały dwie katedry. Pod koniec 1833 roku (30 XII) ogłoszono konkurs na katedrę teologii pastoralnej i wymowy kaznodziejskiej oraz na katedrę historii Kościoła i patrysty$\mathrm{ki}^{64}$. Kandydaci mieli złożyć podania do 20 I 1834 roku. Jednakże w podanym terminie nikt się nie zgłosił, stąd postanowiono trzykrotnie przesunąć datę konkursu ${ }^{65}$. W końcu na katedrę teologiı pastoralnej i wymowy kaznodziejskiej zgłosili się dwaj kandydaci: ks. L. Laurysiewicz ${ }^{60}$ oraz ks. Stanisław Jakliński. Jednakże okazało się że kandydat ks. Jakliński nie posiadal jeszcze doktoratu, stąd poproszono go o przygotowanie takowego i zgłoszenie się do następnego konkursu ${ }^{67}$.

Konkurs, do którego przystapił (jako jedyny kandydat) ks. Laurysiewicz, odbył się dopiero 15 i 16 VII 1836 roku $^{68}$. Ostateczna opinia dziekana ks. Schindlera, o. J. P. Kozłowskiego, ks. J. M. Janowskiego i ks. J. S. Przybylskiego stwierdzała, że ,(...) kandydat jest odpowiednio usposobiony, co do gruntowności lubo zdania nie wyczerpał, dostatecznie jednak odpowiedział życzeniom wydziału..."69.

Kolejny konkurs na katedrę historii Kościoła i patrystyki ogłoszono 17 II 1834 roku, a przystappili do niego: ks. S. Tyczyński (dr teologii i profesor historii Kościoła Uniwersytetu Lwowskiego) oraz F. G. Sosnowski (kanonik katedry lubelskiej $)^{70}$. Wkrótce jednak, Rada Wydziału Teologicznego uznała, że ks. Tyczyński ,(...) jako rzeczywisty profesor historii Kościelnej ma prawo do uwolnienia go od konkursu i przedstawienia do nominacji bez wszelkich innych formalno-

${ }^{62}$ AP, IT 518; AUJ, S I 71: Protokół posiedzeń Senatu Akademickiego Uniwersytetu Jagiellońskiego $\mathrm{z}$ lat $1836-1845$ ( $\mathrm{z}$ wnioskiem o nadanie Schindlerowi doktoratu wystapil J. Brodowicz ,podkreślając jego bezprzykładne poświęcanie się jako Komisarza Zakładów Naukowych, podkreślając przy tym „błogie skutki jego działalności” - tamże) por. J. B i e ni arzów n a, A. S t el m a ch, tamże, s.498; por. M. B a r c i k, Księża doktorzy honoris causa Uniwersytetu Jagiellonskiego (1809-1931), „Analecta Cracoviensia” 18:1986, s. 521-533.

${ }^{63}$ J. B i e n i a r zów n a, A. S te l m a c h, tamże, s. 498-502 (było to przyczyną wzrostu jego kariery i późniejszych awansów aż do chwili objęcia najwyższego stanowiska).

${ }^{64}$ M. K a n i o r, tamże, s. 225.

${ }^{65}$ Tamze. s. 226 (nierwsza data to 5 III 1834, knlejne to 17 IV oraz 17 i 1 18 VII 1834 r)

${ }^{66}$ Laurysiewicz Leon (1798-1854), ksiądz greckokatolicki, profesor Uniwersytetu Krakowskiego. Urodził się 21 III w Preresławicach w guberni lubelskiej. Uczęszczał do szkól średnich w Zamościu i do kolegium pijarskiego w Szczebrzeszynie. Był magistrem teologii i filozofii Uniwersytetu Warszawskiego. Na Wydziale Filozoficznym UJ był profesorem nauki religii. Pełnił tez funkcję administratora parafii greckokatolickiej w kościele św. Norberta w Krakowie. R. D u t k ow a, Laurysiewicz Leon, PSB 16, Wrocław 1971, s. 580.

${ }^{67}$ M. K a n i o r, tamże, s. 226.

${ }^{68}$ AUJ, WT I 3: Liber sessionum. Protokól posiedzeń Wydziatu Teologicznego w Szkole Glównej Krakowskiej z lat 1815-1852; por. M. K a n i o r, tamże, s. 226.

${ }^{69}$ AUJ, WT I 3.

${ }^{70} \mathrm{M}$. K a n i o r, tamże, s. 227. 
ści...”71. Rada Wydziału przyjęła kandydaturę ks. Tyczyńskiego i przesłała ją Senatowi Akademickiemu ${ }^{72}$.

Jak już wspomnieliśmy wcześniej, prace pisemne miały być przesyłane do Akademii Duchownej Rzymsko-Katolickiej w Wilnie (art. 47 Statutu Organicznego). Zarówno prace ks. Laurysiewicza jak i ks. Tyczyńskiego według profesorów Akademii Wileńskiej uznano za dostatecznie nie wyczerpujące zagadnienia ${ }^{73}$. Wbrew ich decyzji Senat Akademicki Wolnego Miasta Krakowa dnia 29 IV 1835 roku zamianował ks. Tyczyńskiego i ks. Laurysiewicza na katedry, o które się ubiegali ${ }^{74}$.

W roku $1835 / 36$ ks. Schindler był zmuszony do przejęcia po śmierci ks. J. Janowskiego wykładów z historii Kościoła i patrystyki do czasu przeprowadzenia nowego konkursu ${ }^{75}$. Pogarszające się zdrowie ks. Schindlera wymagało w roku 1836 regeneracji w postaci wypoczynku. $Z$ taką prośbą zwrócił się pod koniec roku akademickiego do Senatu Uniwersytetu Jagiellońskiego ,....mając zamiar użycia wakacji dla zaratowania zdrowia prosi o wyznaczenie zastępstwa jego w urzędzie dziekańskim Wydziału Teologicznego....”76. Po powrocie $\mathrm{z}$ wakacji, jeszcze w tym samym roku, Schindler musiał zrezygnować z urzędu dziekana, gdyż został mianowany Komisarzem Rządowym Instytutów Naukowych ${ }^{77}$. Ta nominacja otworzyła mu drogę do objęcia najwyższego stanowiska w Rzeczypospolitej Krakowskiej - Prezesa Senatu Wolnego Miasta Krakowa.

${ }^{71}$ AUJ, WT 1 11: Katedra historii koścjelnej z lat $1806-1849$.

${ }^{72}$ M. Ka n i or, tamże, s. 227 (Schindler w listach przesłanych do Senatu popierał znacząco kandydaturę Tyczyńskiego).

${ }^{73}$ Tamże, s. 227.

${ }^{74} \mathrm{M}$. K a n i o r, tamże, s. 228 (ks. Tyczyński wkrótce zrezygnowal z katedry, wtedy rozpisano nowy konkurs).

${ }^{75}$ AUJ, S I 310: Katedra historii kościelnej z lat 1798-1849; por. J. B i e n i a r zó w n a, A. S t e $1 \mathrm{~m}$ a c h, tamże, s. 498; por. M. K a n i o r, tamże, s. 257.

${ }^{76}$ AUJ, S I 71.

77 AUJ, WT I, 10. (Zastępstwo za ks. Schindlera powierzono ks. Przybylskiemu); J. B i en iarzówna, A. Stel ma c h, tamże, s. 498. 


\section{The Beginnings of Teaching Career of Rev. J. Schindler at the Jagiellonian University in the Years 1832-1836 Summary}

Reverend Jan Schindler (1802-1890) was regarded as a controversial figure even during his lifetime and has been considered as such to this day, especially in the Cracow environment. During the period known as the Republic of Cracow (1815-1846) he managed to make a brilliant career in a short time, mostly due to his contacts with the Austrian government.

The year 1832 was a breakthrough in his career. It was then that thanks to archbishop Ankwicz's backing, he got permission to move to the Free City of Cracow. The main reason of Schindler's coming was the nomination for a position of a professor at the Jagiellonian University to lecture on the Bible and eastern languages. 